[Agr. Biol. Chem., Vol. 35, No. 8, p. 1280 1291, 1971]

\title{
Studies on the Mode of Action of Polyoxins
}

\section{Part III. Relation of Polyoxin Structure to Chitin Synthetase Inhibition}

\author{
By Masahiro Hori, ${ }^{`}$ Kazuo Kakiki, Saburo Suzuki and Tomomasa Misato \\ The Institute of Physical and Chemical Research, Wako-shi, Saitama Pref., Japan \\ *Kaken Chemical Co., Ltd., Honkomagome, Bunkyo-ku, Tokyo, Japan
}

Received March 8, 1971

(1) Chitin-UDP acetylglucosaminyltransferase (E.C. 2.4.1.16., chitin synthetase) in the cell-free system from phytopathogenic fungus Piricularia oryzae, and effects of various polyoxins and related compounds on the enzyme activity were studied. Polyoxins $A \sim M$, polyoxin $\mathrm{A}$ derivatives, polyoxin $\mathrm{G}$ derivatives, 5'-amino-5'-deoxyuridine, uridine and thymidine inhibited equally the incorporation of N-acetylglucosamine (GlcNAc) from UDP-Nacetylglucosamine (UDP-GIcNAc) into chitin.

(2) Competition between the above inhibitors and UDP.GlcNAc was observed by kinetic studies. The $K m$ for UDP-GIcNAc was determined to be $3.3 \times 10^{-3} \mathrm{M}$ and the $K i$ values for polyoxins $A \sim M$, except polyoxin $C$, were found to be in the range of $3.3 \times 10^{-5} \mathrm{M}$ to $3.4 \times 10^{-6} \mathrm{M}$. For polyoxin $\mathrm{C}, 5^{\prime}$-amino-5'-deoxyuridine and uridine, the $K i$ values of $2.7 \times$ $10^{-3} \mathrm{M}, 8.0 \times 10^{-3} \mathrm{M}$ and $3.0 \times 10^{-3} \mathrm{M}$ were given, respectively. The inhibitor constants for other related compounds were also calculated.

(3) The values of binding affinity, $-\Delta G$, for formation of substrate- or inhibitor-enzyme complexes were calculated from the $K m$ or $K i$ values. In addition, partial binding affinities, $-\Delta g$, for certain moieties or groups of polyoxins were estimated from the $-\Delta G$. For instance, the $-\Delta G$ values for UDP-GIcNAc and polyoxin $\mathrm{L}$ were $5.7 \mathrm{kcal} / \mathrm{mole}$ and 9.2 $\mathrm{kcal} / \mathrm{mole}$, respectively. And the $-\Delta g$ values for the nucleoside moiety (part $\mathrm{I}^{*}$ ), the carbamylpolyoxamic acid moiety (part $\mathrm{II}^{*}$ ) and the carboxyl group* at $\mathrm{C} 5^{\prime}$ position of polyoxin $\mathrm{L}$ were $5.2,3.5$ and $0.7 \mathrm{kcal} /$ mole, respectively.

(4) From the results obtained, the mechanism of action and relation between chemical structure and competitive inhibition of chitin synthetase were discussed.

Polyoxins $\mathrm{A} \sim \mathrm{M},{ }^{1 /}$ which belong to nucleoside antibiotics produced by Streptomyces cacaoi var. asoensis, are now in practical use as an agricultural fungicides in Japan.

In previous papers, ${ }^{2,3 i}$ Ohta et al. reported that polyoxin $\mathrm{D}$, a component of polyoxins,

\footnotetext{
* See Scheme 2.

1) K. Isono, K. Asahi and S. Suzuki, J. Am. Chem. Soc., 91, 7490 (1969).

2) S. Sasaki, N. Ohta, I. Yamaguchi, S. Kuroda and T. Misato, Nippon Nogeikagaku Kaishi, 42, 633 (1968).

3) N. Ohta, K. Kakiki and T. Misato, Agr. Biol. Chem., 34, 1224 (1970).
}

inhibited cell wall chitin synthesis of some phytopathogenic fungi and induced the accumulation of UDP-GlcNAc, an intermediate of chitin biosynthesis.

Recent studies using cell-free systems of $P$. oryzae $e^{3 \prime}$ and Neurospora crassa ${ }^{4}$ showed that polyoxin D strongly inhibited chitin synthetase in competition with UDP-GlcNAc. ${ }^{4 !}$

Because polyoxins are the first antibiotics which inhibit fungal cell wall synthesis, it

\footnotetext{
4) A. Endo and T. Misato, Biochem. Biophys. Res. Commun., 37, 718 (1969).
} 
should be very interesting to study their effect ate the relationships among chitin synthetase, on chitin synthesis in cell free system. It is UDP-GIcNAc and polyoxins. Polyoxins A expected that an analogy between polyoxins $\mathrm{M}$, polyoxin $\mathrm{A}$ derivatives, polyoxin $\mathrm{C}$ deriand UDP-GlcNAc provides a structural basis vatives and other related compounds, which for the inhibition of chitin synthesis. "

structures are shown in Scheme 1, are used In the present paper, we attempt to elucid- in the present studies.

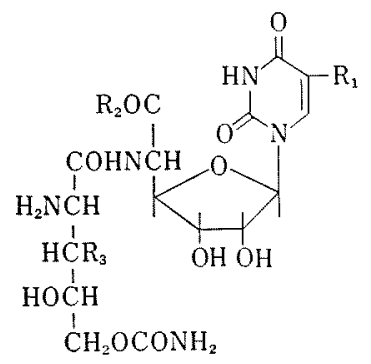

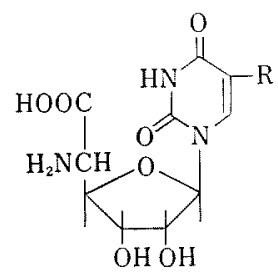

$\mathrm{R}$

Polyoxin $\mathrm{C} \quad \mathrm{CH}_{2} \mathrm{OH}$

Polyoxin $\mathrm{C}$ acid $\mathrm{COOH}$

Uracil polyoxin $\mathrm{C} \quad \mathrm{H}$

Thymine polyoxin $\mathrm{C} \quad \mathrm{CH}_{3}$

\begin{tabular}{clll} 
Polyoxin & \multicolumn{1}{c}{$\mathrm{R}_{1}$} & $\mathrm{R}_{2}$ & \multicolumn{1}{c}{$\mathrm{R}_{3}$} \\
A & $\mathrm{CH}_{2} \mathrm{OH}$ & $*$ & $\mathrm{OH}$ \\
B & $\mathrm{CH}_{2} \mathrm{OH}$ & $\mathrm{HO}$ & $\mathrm{OH}$ \\
D & $\mathrm{COOH}$ & $\mathrm{HO}$ & $\mathrm{OH}$ \\
E & $\mathrm{COOH}$ & $\mathrm{HO}$ & $\mathrm{H}$ \\
F & $\mathrm{COOH}$ & $*$ & $\mathrm{OH}$ \\
G & $\mathrm{CH}_{2} \mathrm{OH}$ & $\mathrm{HO}$ & $\mathrm{H}$ \\
$\mathrm{H}$ & $\mathrm{CH}_{3}$ & $*$ & $\mathrm{OH}$ \\
$\mathrm{J}$ & $\mathrm{CH}_{3}$ & $\mathrm{HO}$ & $\mathrm{OH}$ \\
K & $\mathrm{H}$ & $*$ & $\mathrm{OH}$ \\
$\mathrm{L}$ & $\mathrm{H}$ & $\mathrm{HO}$ & $\mathrm{OH}$ \\
$\mathrm{M}$ & $\mathrm{H}$ & $\mathrm{HO}$ & $\mathrm{H}$
\end{tabular}<smiles>CC1=C(C)C(C(=O)O)CN=C1</smiles><smiles>CC1(O)OC2(n3ccc(=O)[nH]c3=O)OC1C(O)C2O</smiles>

Uridine<smiles>NC(=O)CC(O)C(O)C(=O)O</smiles><smiles>O=C(O)C(O)C(O)C(O)CO</smiles>

Carbamylpolyoxamic acid

SCHEME 1 


\section{M.ATERIALS AND METHODS}

Chemicals. Polyoxins A, B, D, E, F, G, K, L, M, uracil polyoxin $\mathrm{C}^{11}$ and polyoxin $\mathrm{C}$ acid were obtained from Kaken Chemical Co., Ltd. Polyoxins C, H, J, $\mathrm{N}$-acetylpolyoxin $A,{ }^{11}$ deaminopolyoxin $\mathrm{A},{ }^{1 !}$ thymine polyoxin $\mathrm{C}^{21}$ and other related substances were generous gifts from Dr. K. Isono, Institute of Physical and Chemical Research. D-Glucosamine-1-14C was purchased from Radiochemical Centre, England, and UDP-Glc.N-Ac- ${ }^{14} \mathrm{C}$ was prepared according to the method described previously. ${ }^{5}$ Chitinase and unlabeled UDP-GlcNAc were purchased from Nutritional Biochemicals and SIGMAA, respectively. Soluble chitodextrin was prepared by acetolysis of commercial chitin (solvent mixture of acetic anhydride/conc sulphuric acid, (20:1), was used). ${ }^{61}$

Organisms and growth conditions. Piricularia oryzae $\mathrm{P}_{2}$, which was obtained from National Institute of Agricultural Sciences, Tokyo, was grown in Y.G. liquid medium (glucose $20^{\circ}$, yeast extract $0.40^{\circ}$ ) for $44 \mathrm{hr}$ at $28^{\circ} \mathrm{C}$ with resiprocal shaking. Neurospora crassa wild strain IFO 6068 was grown in Vogel's medium $^{7 /}$ under the same conditions as $P$. oryzae.

Preparation of enzyme. Mycelia $(10 \mathrm{~g})$ of P. oryzae were harvested by filtration and washed three times with ice cold $1 / 20 \mathrm{M}$ Tris-HCl buffer ( $\mathrm{pH} \mathrm{7.8)} \mathrm{con-}$ taining $5 \mathrm{mM} \mathrm{MgCl}_{2}$ and $0.5 \mathrm{~mm}$ EDTA. The washed mycelia were suspended in $20 \mathrm{ml}$ of the same buffer and then disrupted by grinding with $10 \mathrm{~g}$ of sands in a glass homogenizer at $0^{\circ} \mathrm{C}$ for $10 \mathrm{~min}$. This homogenate was centrifuged at $15,000 \times g$ for $30 \mathrm{~min}$ and the supernatant fraction was again centrifuged at $150,000 \times g$ for $60 \mathrm{~min}$. The precipitate obtained by the second centrifugation was suspended in $2 \mathrm{ml}$ of the above buffer and this suspension was used as enzyme solution.

Assay of enzyme activity. Incubation mixtures contained $25 \mathrm{mM}$ Tris- $\mathrm{HCl}, 2.5 \mathrm{mM} \quad \mathrm{MgCl}_{2}, 0.25 \mathrm{mM}$ EDTA, $25 \mathrm{~mm}$ Glc.I.Ac, $1.5 \mathrm{~mm}$ UDP-GlcN.Ac- ${ }^{14} \mathrm{C}$,

5) A. Endo, K. Kakiki, M. Hori, H. Abe and T. Misato, Biochem. Biophys. Res. Commun., 39, 718 (1970).

6) P. Perchemlider, T. Osawa, E.A. Davidson, and R. W. Jeanloz, Carbohydrate Res., 3, 463 (1963); J. Conchie, G.A. Levvy and C.A. Marsh, Advances in Carbohyd. Chem., 12, 157 (1957).

7) H. J. Vogel, Microbial Genet. Bull., 13, 42 (1956).
$0.25 \mathrm{mg}$ of soluble chitodextrin and $50 \mu \mathrm{l}$ of the enzyme solution in a total volume of $100 \mu \mathrm{l}$. Incubations were made for $15 \mathrm{~min}$ at $24^{\circ} \mathrm{C}$ or for $120 \mathrm{~min}$ at $20^{\circ} \mathrm{C}$. The reaction was stopped by heating the mixtures in a boiling water bath for $1 \mathrm{~min}$. The reaction mixtures were spotted on the cellulose powder (Avicel SF) thin layer plate. Chromatography was performed overnight in isobutyric acid/1 $\mathrm{N}$ ammonium hydroxide $(5: 3)$. Radioactive products remained at origins of the TLC plate (see Fig. 1) were cut out and counted on Beckman liquid scintilation spectrometer.

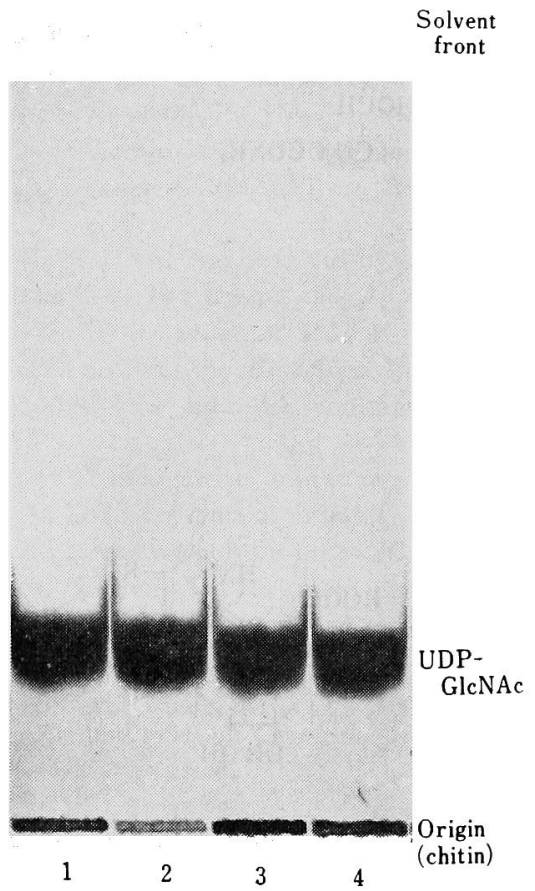

FIG. 1. A Radioautogram on Synthesis of Chitin and Effect of Polyoxin D.

Tubes of 1, 2 and 3, 4 were incubated for 5 $\mathrm{min}$ and $15 \mathrm{~min}$, respectively. Polyoxin D (19 $\mu \mathrm{M})$ was contained in the tubes 2 and 4 . Other conditions of the experiment were the same as described in Fig. 5.

\section{RESULTS}

\section{Formation of water insoluble material}

When the particulate enzyme from $P$. oryzae 
was incubated under the conditions described above, formation of a chromatographycally immobile product was observed (Fig. 1). This material was water insoluble and digesting with chitinase, gave a degradation product which was identified as GlcNAc by Avicel SF TLC (isobutyric acid/1 $\mathrm{N}$ ammonium hydroxide, 5:3).

Effects of addition of GlcN.Ac and soluble chitodextrin

The addition of GlcNAc resulted in about 5-to 10-fold stimulation of chitin synthetase activity (Fig. 2). Half maximal activation of the enzyme was obtained at $9.5 \times 10^{-3} \mathrm{M}$ GlcNAc. The soluble chitodextrin also stimulated the formation of chitin in the presence of $50 \mathrm{mM}$ GlcNic (Fig. 3). In the presence of both GlcNAc and the soluble chitodextrin, stable chitin synthetase activity was usually obtained. On the other hand the enzyme

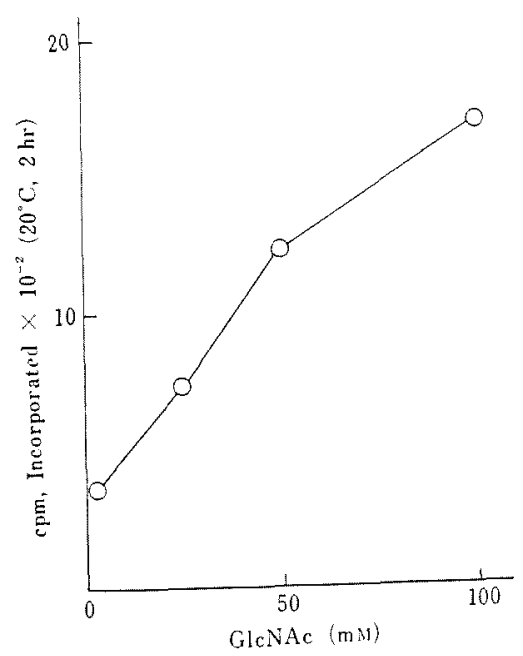

EIG. 2. Effect of X-Acetylglucosamine (GlcNAc) on Chitin Synthesis.

The reaction mixture contained $2 \mathrm{mM}$ UDPGlcNAc- ${ }^{14} \mathrm{C}(8000 \mathrm{cpm}), 25 \mathrm{~mm}$ Tris-HCl, $2.5 \mathrm{mM}$ $\mathrm{MgCl}_{2}, 0.25 \mathrm{mM}$ EDTA and $50 \mu$ of the enzyme solution from $P$. oryzae in a total volume of 100 $\mu 1, \mathrm{pH}$ 7.8. GlcNAc was added as indicated. Incubation was for $120 \mathrm{~min}$ at $20^{\circ} \mathrm{C}$. activity was very unstable without the addition of the soluble chitodextrin.

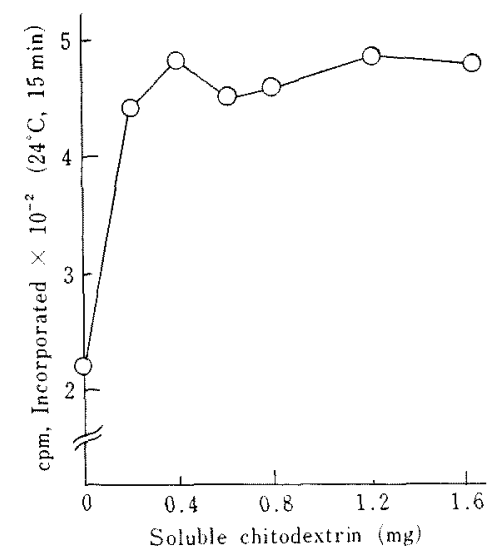

FIG. 3. Effect of Soluble Chitodextrin on Chitin Synthesis.

The reaction mixture contained $1 \mathrm{mM}$ UDP-Glc$\mathrm{NAc}-{ }^{14} \mathrm{C} \quad(10,000 \mathrm{cpm}), 25 \mathrm{~mm}$ Tris- $\mathrm{HCl}, 2.5 \mathrm{~mm}$ $\mathrm{MgCl}_{2}, 0.25 \mathrm{~mm}$ EDTA, $\{50 \mathrm{~mm} \mathrm{GlcNAc}$ and $20 \mu \mathrm{l}$ of the enzyme solution from $P$. oryzae in a total volume of $40 \mu, \mathrm{pH}$ 7.8. Soluble chitodextrin was added as indicated. Incubation was for 15 $\min$ at $24^{\circ} \mathrm{C}$.

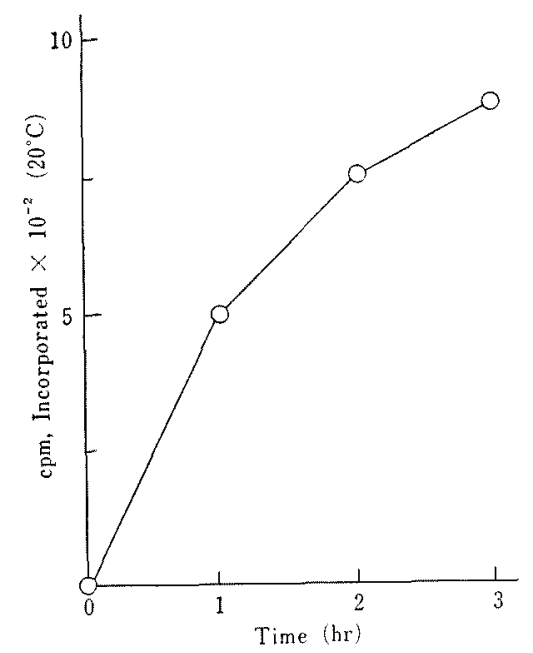

FIG. 4. Time Course of Chitin Synthesis.

The experiment was carried out as described in Fig. 2 and GlcNAc was added at the concentration of $25 \mathrm{~mm}$. 
Time course of chitin synthesis

The synthesis of chitin was almost linear during the first 120 min under the conditions described in Fig. 4, while a linearity was observed during the first $15 \mathrm{~min}$ under the another conditions in Fig. 5.

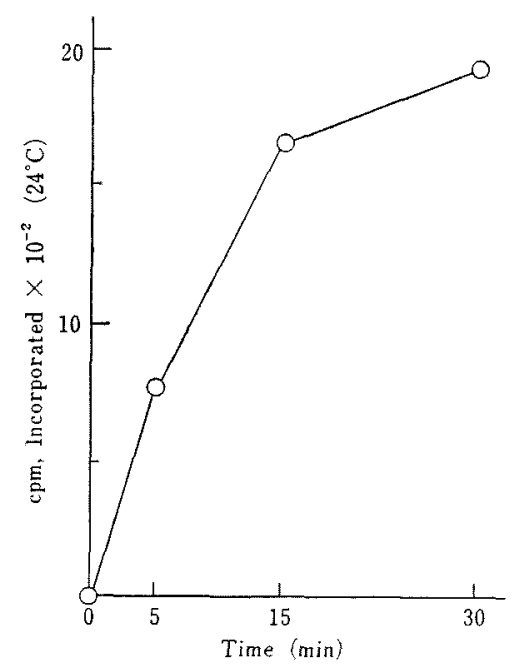

FIG. 5. Time Course of Chitin Synthesis.

The reaction mixture contained $1.5 \mathrm{mM}$ UDPGlcNAc- ${ }^{14} \mathrm{C} \quad(19,000 \mathrm{cpm}), 25 \mathrm{~mm}$ Tris-HCl, 2.5 $\mathrm{mM} \mathrm{MgCl} 2,0.25 \mathrm{mM}$ EDTA, $50 \mathrm{mM}$ GlcNAc, 0.1 $\mathrm{mg}$ of soluble chitodextrin and $10 \mu l$ of the enzyme solution from $P$. oryzae in a total volume of $25 \mu 1, \mathrm{pH} 7.8$. Incubation was at $24^{\circ} \mathrm{C}$ for the periods indicated.

\section{Michaelis constant}

From the data in Fig. 6, it was calculated that the $K m$ for UDP-GlcNAc was $3.3 \times 10^{-3} \mathrm{M}$ in the presence of GlcNAc and soluble chitodextrin.

\section{Effects of polyoxins" and related compounds*}

Polyoxins $\mathrm{A} \sim \mathrm{M}$, except polyoxin $\mathrm{C}$, caused $50 \%$ inhibition of chitin synthetase at the concentrations in the range of 5 to $25 \mu \mathrm{g} / \mathrm{ml}$ (Table I). By removal or acetylation of the amino group at $\mathrm{C}_{2}^{\prime \prime}$ position, however, the inhibitory activity of polyoxin A was greatly

\footnotetext{
* See Scheme 1.
}

Table I. Effects of Various Polyoxins on ChITIN SynThesis in $P$, oryzae.

The reaction mixture contained $2 \mathrm{mM}$ UDP-GlcNAc${ }^{14} \mathrm{C}(4,000 \mathrm{cpm}), 25 \mathrm{~mm}$ Tris- $\mathrm{HCl}, 2.5 \mathrm{mM} \mathrm{MgCl}_{2}$, $0.25 \mathrm{mM}$ EDTA, $25 \mathrm{mM}$ GlcNAc, $0.5 \mathrm{mg}$ of soluble chitodextrin and $50 \mu 1$ of enzyme solution from $P$. oryzae in a total volume $100 \mu \mathrm{l}, \mathrm{pH} 7.8$. Incubation was for $120 \mathrm{~min}$ at $20^{\circ} \mathrm{C}$.

\begin{tabular}{|c|c|c|c|}
\hline \multicolumn{2}{|c|}{$\begin{array}{l}\text { Amount of polyoxins } \\
\text { and related substances } \\
\text { added, }(\mu \mathrm{g} / \mathrm{ml})\end{array}$} & \multirow{2}{*}{ 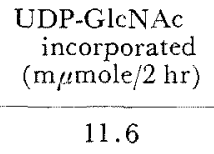 } & \multirow[t]{2}{*}{$\begin{array}{l}\text { Percent } \\
\text { inhibition }\end{array}$} \\
\hline None (con & & & \\
\hline \multirow[t]{6}{*}{ Polyoxin A } & 10 & 7.2 & 39 \\
\hline & 100 & 1.5 & 87 \\
\hline & 10 & 4.2 & 64 \\
\hline & 100 & 0.6 & 95 \\
\hline & 10 & 12.3 & 0 \\
\hline & 100 & 10.7 & 8 \\
\hline \multirow[t]{2}{*}{ D } & 10 & 6.1 & 47 \\
\hline & 100 & 1.3 & 89 \\
\hline \multirow[t]{2}{*}{$\mathrm{E}$} & 10 & 9.9 & 15 \\
\hline & 100 & 6.8 & 41 \\
\hline \multirow[t]{2}{*}{$F$} & 10 & 6.0 & 48 \\
\hline & 100 & 1.6 & 86 \\
\hline \multirow[t]{2}{*}{ G } & 10 & 7.7 & 34 \\
\hline & 100 & 2.0 & 82 \\
\hline \multirow[t]{2}{*}{$\mathrm{K}$} & 10 & 7.4 & 37 \\
\hline & 100 & 1.8 & 85 \\
\hline \multirow[t]{2}{*}{$\mathrm{L}$} & 10 & 5.4 & 53 \\
\hline & 100 & 1.5 & 87 \\
\hline \multirow[t]{2}{*}{$\mathrm{M}$} & 10 & 9.6 & 17 \\
\hline & 100 & 6.5 & 44 \\
\hline \multicolumn{2}{|c|}{$\begin{array}{r}\text { N-Acetylpolyoxine A } \\
1000\end{array}$} & 9.7 & 17 \\
\hline \multicolumn{2}{|c|}{$\begin{array}{r}\text { Deaminopolyoxin A } \\
1000\end{array}$} & 8.3 & 29 \\
\hline
\end{tabular}

lowered. Although it has so far been regarded that polyoxin $\mathrm{C}^{8)}$ and its derivatives have no biological activity, the inhibition of chitin synthetase by them were observed at the high concentration as shown in Table II. Uridine and $5^{\prime}$-amino-5'-deoxyuridine ${ }^{9 \prime}$ also inhibited the enzyme, but by uracil, carbamylpolyoxamic acid ${ }^{11}$ and polyoxamic acid, ${ }^{11}$ the synthetic

8) K. Isono, J. Nagatsu, K. Kobinata, K. Sasaki and S. Suzuki, Agr. Biol. Chem., 31, 190 (1967).

9) K. Isono, T. Azuma and S. Suzuki, Chem. Pharm. Bull., 19, 505 (1971). 
TABle II. EFfects of Polyoxin C, POLYOXIN C Derivatives and Other Related SubSTANCES on Chitin Synthesis in $P$. oryzae

The experiment was carried out as described in Table I.

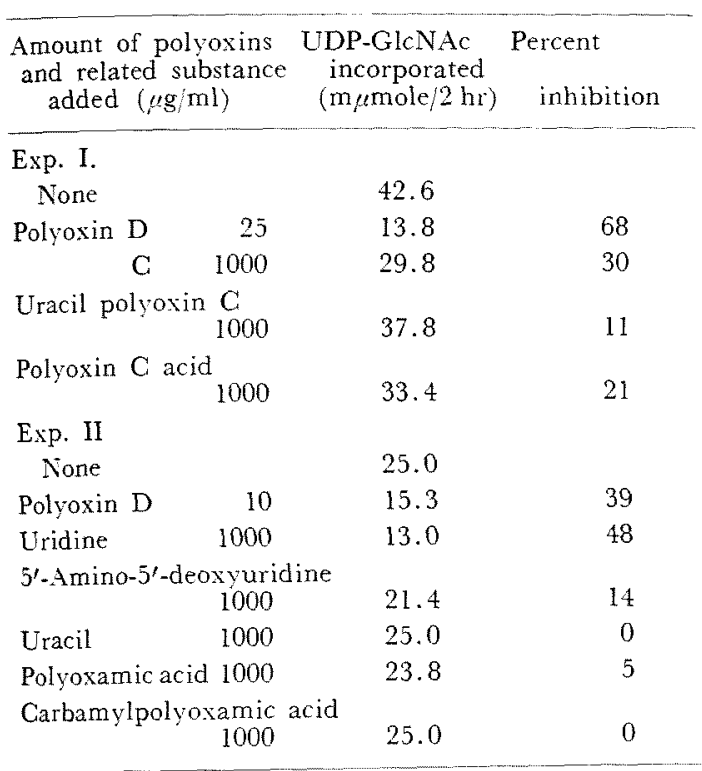

reaction was not inhibited at the concentration of $1,000 \mu \mathrm{g} / \mathrm{ml}$ (Table II).

The effects of the various inhibitors of chitin synthetase on the reaction velocity at various UDP-GlcNAc concentrations were investigated and the data obtained were plotted according to Lineweaver and Burk ${ }^{10 !}$ (Fig. 6, Fig. 7, Fig. 8, Fig. 9).

It was found that the relationships between UDP-GlCNAC and the all inhibitors were evidently competitive. In addition, the finding that uridine was a competitor for UDP-GlcNAc was also confirmed by Dixon plot ${ }^{11 !}$ (Fig. 10).

In addition to uridine, some other nucleosides were used to examine their effects on the chitin synthetase. As shown in Table III, uridine and thymidine inhibited the enzyme at the concentrations of 250 and $1,000 \mu \mathrm{g} / \mathrm{ml}$.

10) H. Lineweaver and D. Burk, J. Am. Chem. Soc, 56, 658 (1934).

11) M. Dixon, Biochem. J., 55, 170 (1953).

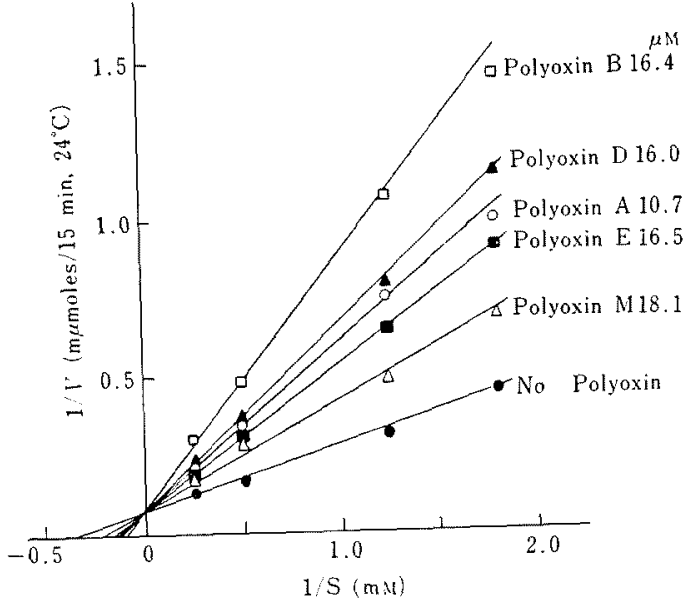

FIG. 6. Competitive Inhibition of Chitin Synthetase by Polyoxins.

Assays were carried out as described in the text except that the reaction mixture contained UDP. GlcNAc- ${ }^{44} \mathrm{C}(15,000 \mathrm{cpm})$ at the various concentrations. Polyoxins A, B, D, E and $\mathrm{M}$ were added at the concentrations indicated. Incubation was for $15 \mathrm{~min}$ at $24^{\circ} \mathrm{C}$. Data were plotted according to Lineweaver and Burk.

However other nucleosides including cytidine, which have a pyrimidine base like the above two nucleosides showed no inhibition.

Other antibiotics such as penicillin, bacitracin, cycloserine, cycloheximide and griseofulvin did not inhibit chitin synthetase in this system at the concentration of $800 \mu \mathrm{g} / \mathrm{ml}$.

\section{Inhibitor constant}

From the data in Fig. 6 9, the $K i$ values for various polyoxins and other related substances were calculated (Table IV).

In the case of polyoxins $A \sim M$, except polyoxin $\mathrm{C}$, the $K i$ values were in the range of $3.3 \times 10^{-5} \mathrm{M}$ to $3.4 \times 10^{-6} \mathrm{M}$ were about 100 to 1,000 times higher than the $K m$ value for UDP-GICNAC $\left(3.3 \times 10^{-3} \mathrm{M}\right)$. When the amino group at $\mathrm{C}_{2}{ }^{\prime \prime}$ position of polyoxin $\mathrm{A}$ was removed (deaminopolyoxin A) or acetylated ( $N$ acetylpolyoxin $\mathrm{A}$ ), the $K i$ for the derivatives were increased about 100 times. In polyoxins 


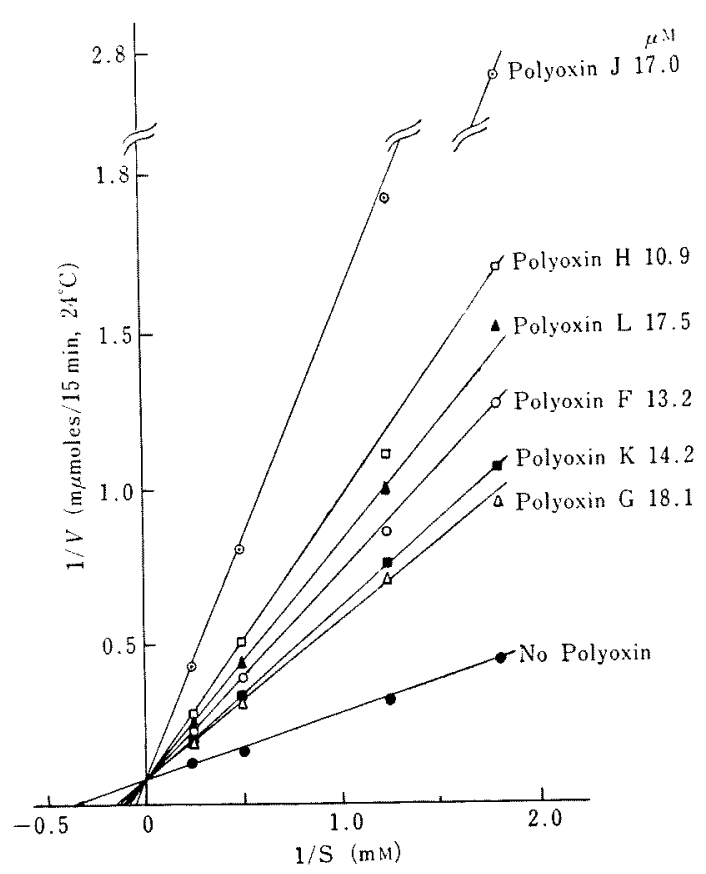

FIG. 7. Competitive Inhibition of Chitin Synthetase by Polyoxins.

The experiment was carried out as described in Fig. 6. Polyoxins F, G, H, J, K and $\mathrm{L}$ were used as indicated.

with a methyl group as a substituent at the $\mathrm{R}_{1}$ position, such as polyoxins $\mathrm{H}$ and $\mathrm{J}$, the inhibitory activities of them were approximately doubled compared with those of polyoxins $\mathrm{A}, \mathrm{B}, \mathrm{D}, \mathrm{F}$ and $\mathrm{L}$. The $K i$ values for polyoxins $\mathrm{E}, \mathrm{G}$ and $\mathrm{M}$ were about 3 times larger than those for polyoxins with a hydroxyl group as $\mathrm{R}_{3}$ such as polyoxins $\mathrm{B}, \mathrm{D}$ and $\mathrm{L}$.

On the $K i$ values for a series of compounds related to polyoxin $\mathrm{C}$, several interesting findings were obtained. The $K i$ for polyoxin $\mathrm{C}$ was $2.7 \times 10^{-3} \mathrm{M}$ and was the same order as the $K m$ value. The $K i$ for uracil polyoxin $\mathrm{C}$ and its decarboxylated compound, 5'-amino-5'-deoxyuridine (see Scheme 1), were $2.5 \times 10^{-3} \mathrm{M}$ and $8.0 \times 10^{-3} \mathrm{M}$, respectively. From the data in either Figs. 9 and 10 , the $K i$ for uridine was calculated as $3.0 \times 10^{-3} \mathrm{M}$.

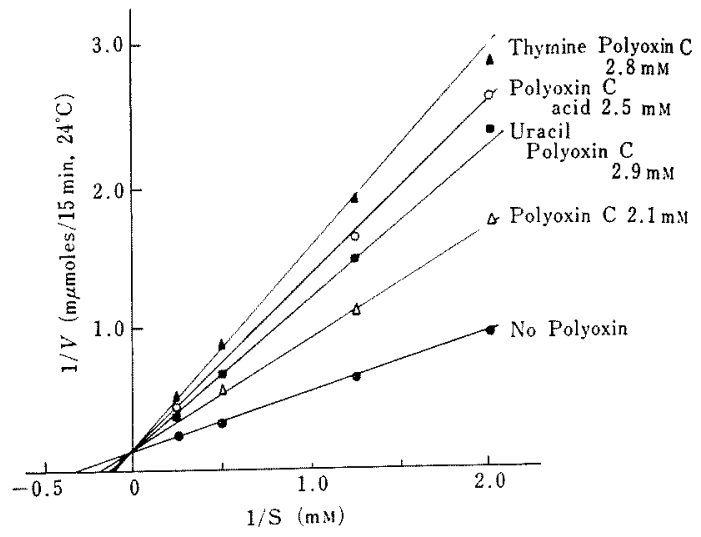

FJG. 8. Competitive Inhibition of Chitin Synthetase by Polyoxins.

Assays were carried out as described in the text except that reaction mixture contained UDP-Glc$\mathrm{NAc}-{ }^{14} \mathrm{C}(15,000 \mathrm{cpm})$ at the various concentrations indicated. Polyoxin $\mathrm{C}$, polyoxin $\mathrm{C}$ acid, thymine polyoxin $\mathrm{C}$ and uracil polyoxin $\mathrm{C}$ were added at the concentrations indicated. Incubation was for $15 \mathrm{~min}$ at $24^{\circ} \mathrm{C}$.

Table III. EFFects of Various Nucleosides ON CHITIN Synthesis IN $P$, oryzae

The experiment was carried out as described in the text except that the incubation was for $30 \mathrm{~min}$ at $24^{\circ} \mathrm{C}$ and the concentration of UDP-GICNAc- ${ }^{14} \mathrm{C}$ $(10,500 \mathrm{cpm})$ was $1.25 \mathrm{mM}$.

\begin{tabular}{crcr}
\hline $\begin{array}{c}\text { Amount of nuclea- } \\
\text { sides added } \\
\text { (ug/ml) }\end{array}$ & $\begin{array}{c}\text { UDP-GlcNAc } \\
\text { incorporated } \\
\text { (m } / \text { mole/30 min) }\end{array}$ & $\begin{array}{c}\text { Percent } \\
\text { inhibition }\end{array}$ \\
\hline \multicolumn{2}{c}{ None (control) } & 42.5 & \\
Adenosine & 1000 & 40.5 & \\
Cytidine & 250 & 41.3 & \\
& 1000 & 43.0 & \\
Guanosine & 250 & 40.4 & \\
& 1000 & 43.8 & \\
Inosine & 250 & 42.6 & \\
& 1000 & 42.4 & \\
Thymidine & 250 & 43.2 & \\
& 1000 & 31.7 & 24 \\
Uridine & 250 & 36.7 & 12 \\
& 1000 & 19.4 & 55 \\
Xanthosine & 250 & 23.6 & 43 \\
& 1000 & 44.1 & \\
\hline
\end{tabular}




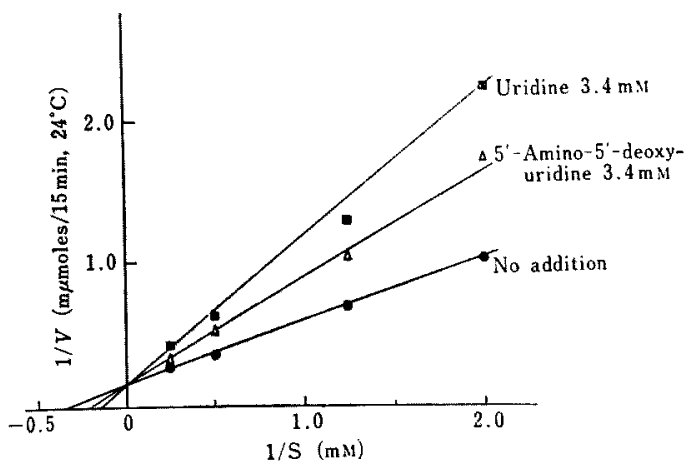

FIG. 9. Competitive Inhibition of Chitin Synthetase by Uridine and 5'-Amino-5'-deoxyuridine.

The experiment was carried out as described in Fig. 8 except that uridine and $5^{\prime}$-amino-5'-deoxyuridine were added instead of polyoxins at the concentrations indicated.

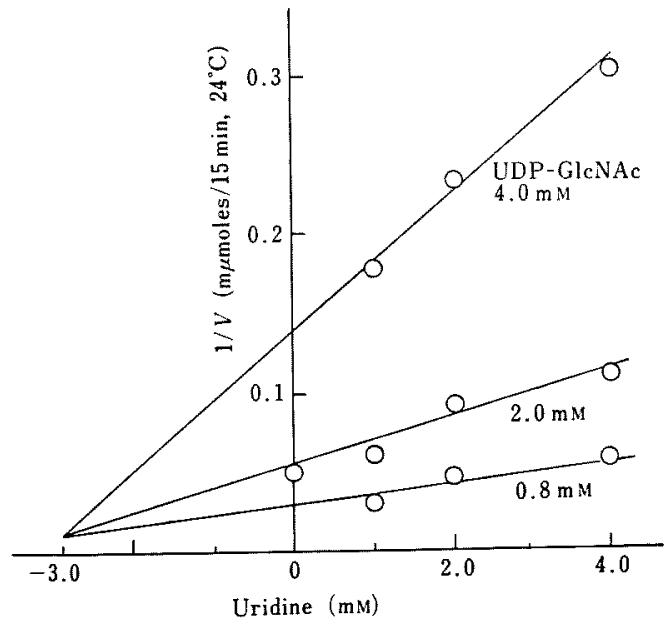

FIg. 10. Competitive Inhibition of Chitin Synthetase by Uridine.

The experiment was carried out as described in the text except that the reaction mixture were contained UDP-GIcNAc- ${ }^{14} \mathrm{C}(10,500 \mathrm{cpm})$ and uridine at the various concentrations indicated. Incubation was for $15 \mathrm{~min}$ at $24^{\circ} \mathrm{C}$. Data were plotted according to the method of Dixon.

\section{Binding affinity}

As a measure of the strength of the binding between the enzyme and UDP-GlcNAc
TABle IV. VAlUes of Inhibitor Constant, $K i$, AND BINDING AFFINITY, $-\Delta G$, FOR POLyOXINS AND Related Compounds

The $K m$ and the $-\Delta G$ for substrate UDP-GlcNAc were $3.3 \times 10^{-3} \mathrm{M}$ and $5.7 \mathrm{kcal} / \mathrm{mole}$, respectively.

\begin{tabular}{ccc}
\hline $\begin{array}{c}\text { Competitive inhibitors } \\
\text { of chitin synthetase }\end{array}$ & $K i(\mathrm{M})$ & $\begin{array}{c}-A G \\
\left(\mathrm{kcal} / \mathrm{mole}, 24^{\circ} \mathrm{C}\right)\end{array}$ \\
\hline Polyoxin A & $1.1 \times 10^{-\mathrm{b}}$ & 9.0 \\
$\mathrm{~B}$ & $5.6 \times 10^{-6}$ & 9.4 \\
$\mathrm{D}$ & $1.2 \times 10^{-5}$ & 9.0 \\
$\mathrm{E}$ & $3.3 \times 10^{-5}$ & 8.4 \\
$\mathrm{~F}$ & $7.5 \times 10^{-6}$ & 9.2 \\
$\mathrm{G}$ & $1.5 \times 10^{-5}$ & 8.7 \\
$\mathrm{H}$ & $3.9 \times 10^{-6}$ & 9.6 \\
$\mathrm{~J}$ & $3.4 \times 10^{-6}$ & 9.7 \\
$\mathrm{~K}$ & $1.1 \times 10^{-5}$ & 9.0 \\
$\mathrm{~L}$ & $8.1 \times 10^{-6}$ & 9.2 \\
M & $2.1 \times 10^{-5}$ & 8.6 \\
N-Acetylpolyoxin A & $1.1 \times 10^{-3}$ & 6.4 \\
Deaminopolyoxin A & $8.6 \times 10^{-4}$ & 6.5 \\
Polyoxin C & $2.7 \times 10^{-3}$ & 5.8 \\
Uracil polyoxin C & $2.5 \times 10^{-3}$ & 5.9 \\
Thymine polyoxin C & $1.4 \times 10^{-3}$ & 6.2 \\
Polyoxin C acid & $1.5 \times 10^{-3}$ & 6.2 \\
Uridine & $3.0 \times 10^{-3}$ & 5.8 \\
5'Amino-5'-deoxyuridine $8.0 \times 10^{-3}$ & 5.2 \\
\hline
\end{tabular}

Table V. Values of Partial Binding Affinity, $-\Delta g$, FOR VARIOUS MOIETIES ${ }^{a}$ ) OR GROUPS ${ }^{a}$ ) OF POLYOXINS

\begin{tabular}{|c|c|c|}
\hline & $\begin{array}{l}\text { Calculation methods } \\
(-\Delta G) \text { polyoxin } \mathrm{X}^{-} \\
(-\Delta G) \text { polyoxin } \mathrm{Y}\end{array}$ & $\begin{array}{l}-\Delta g \\
(\mathrm{kcal} / \mathrm{mole} \\
\left.24^{\circ} \mathrm{C}\right)\end{array}$ \\
\hline Part I $\quad\left(\mathrm{R}_{1}=\mathrm{H}\right)$ & & 5.2 \\
\hline Part II $\left(\mathrm{R}_{3}=\mathrm{OH}\right)$ & $\begin{array}{l}(\mathrm{B})-(\mathrm{C}) \\
(\mathrm{L})-(\text { uracil } \mathrm{C}) \\
(\mathrm{J})-(\text { thymine } \mathrm{C})\end{array}$ & $\left.\begin{array}{l}3.6 \\
3.3 \\
3.5\end{array}\right\} 3.5^{b\}}$ \\
\hline Part II $\left(\mathrm{R}_{3}=\mathrm{H}\right)$ & $\begin{array}{l}(\mathrm{G})-(\mathrm{C}) \\
(\mathrm{M})-(\text { uracil } \mathrm{C})\end{array}$ & $\left.\begin{array}{l}2.9 \\
2.9\end{array}\right\} 2.9^{61}$ \\
\hline$-\mathrm{COOH}$ at $\mathrm{C}^{\prime}$ & $\begin{array}{c}\text { (uracil C) }-\left(5^{\prime} \text {-amin }\right. \\
\left.5^{\prime} \text {-deoxyuridine }\right)\end{array}$ & 0.7 \\
\hline$-\mathrm{NH}_{2} \quad$ at $\mathrm{C} 22^{\prime \prime}$ & $\begin{array}{l}(\mathrm{A})-(\text { deamino } \mathrm{A}) \\
(\mathrm{A})-(\text { N-acetyl A })\end{array}$ & $\left.\begin{array}{l}2.2 \\
2.0\end{array}\right\} 2.1^{61}$ \\
\hline$-\mathrm{OH}$ at $\mathrm{C} 3^{\prime \prime}$ & $\begin{array}{l}(B)-(G) \\
(D)-(\mathrm{E}) \\
(\mathrm{L})-(\mathrm{M})\end{array}$ & $\left.\begin{array}{l}0.6 \\
0.6 \\
0.6\end{array}\right\} 0.6^{b 1}$ \\
\hline$-\mathrm{CH}_{3}$ at $\mathrm{C} 5$ & $\begin{array}{l}(\mathrm{H})-(\mathrm{K}) \\
(\mathrm{J})-(\mathrm{L})\end{array}$ & $\begin{array}{l}0.6 \\
0.5\end{array} \mid 0.6^{b\}}$ \\
\hline
\end{tabular}

a) See Scheme 2.

b) Mean of $-\Delta g$ values. 
or polyoxins, we used a so-called binding affinity, ${ }^{12}-\Delta G^{*}$, which could be calculated from the $K m(\risingdotseq K s)$ value or the $K i$ value. The larger the value of $-\Delta G$, the greater the affinity of UDP-GICNAc or polyoxins for the enzyme. From the $K i$ values described above the $-\Delta G$ values were calculated (Table IV). In addition, since it was assumed that polyoxins were bound to the enzyme through several moities and groups of their molecules the values of partial binding affinity, ${ }^{12}$ $-\Delta g^{* *}$, for certain moieties and groups of polyoxins were calculated from the above $-\Delta G$ values (Table $\mathrm{V}$ ).

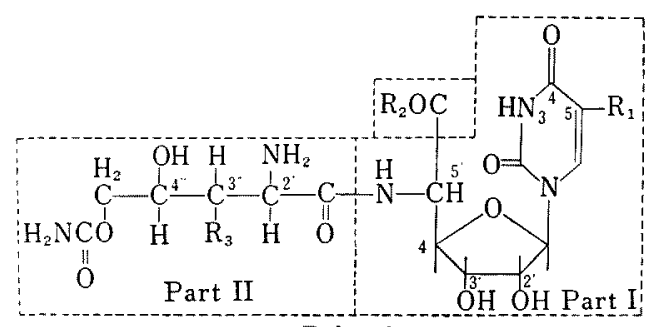

Polyoxin

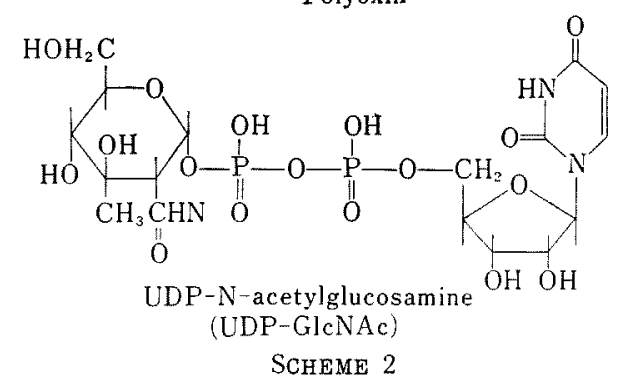

As shown in Scheme 2, polyoxin structures can be divided into three parts. In the case of polyoxin $\mathrm{L}$, the $-\Delta G$ value was $9.2 \mathrm{kcal} /$ mole. This value and the sum of the $-\Delta g$ values for part I $(5.2 \mathrm{kcal} / \mathrm{mole})$, part II $(3.5$ $\mathrm{kcal} / \mathrm{mole})$ and carboxyl group at $\mathrm{C}^{\prime}$ position $(0.7 \mathrm{kcal} / \mathrm{mole})$ were approximately equal. The

12) W. Kauzmann, Advance in Protein Chemistry, 14, 1 (1959); D.M. Chipman and N. Sharon, Science, 165, 454 (1969); Y. Nitta, Protein Nucleic Acid Enzyme, 15, $1262(1970)$.

* $-\Delta G=-R T \ln K+2.4\left(\mathrm{kcal} / \mathrm{mole}, 24^{\circ} \mathrm{C}\right)$

** $-\Delta G=-\left(\Delta g_{1}+\Delta g_{2}+\Delta g_{3}+\cdots \cdots\right)$
$-\Delta G$ values for polyoxin $\mathrm{C}$ and a series of related compounds of it were in the range of $5.2 \sim 6.2 \mathrm{kcal} / \mathrm{mole}$. The $-\Delta g$ value for the amino group at $\mathrm{C} 2$ " position was $2.1 \mathrm{kcal} / \mathrm{mole}$ and was a fairly great value compared with the $-\Delta G$ value for whole molecule of polyoxin.

When it was assumed that $K s \risingdotseq K m$, the $-\Delta G$ value for UDP-GlcNAc was $5.7 \mathrm{kcal} / \mathrm{mole}$.

\section{Particulate enzyme from $N$. crassa}

Enzyme was prepared according to method as used in $P$. oryzae. The particulate fraction obtained from the second centrifugation was suspended in $8 \mathrm{ml}$ of $1 / 20 \mathrm{M}$ Tris- $\mathrm{HCl}$ buffer, $\mathrm{pH} 7.8$, containing $5 \mathrm{mM} \mathrm{MgCl}_{2}$ and $0.5 \mathrm{~mm}$ EDTA, and was used as an enzyme solution.

When the particulate enzyme was incubated under the conditions shown in Fig. 11, the

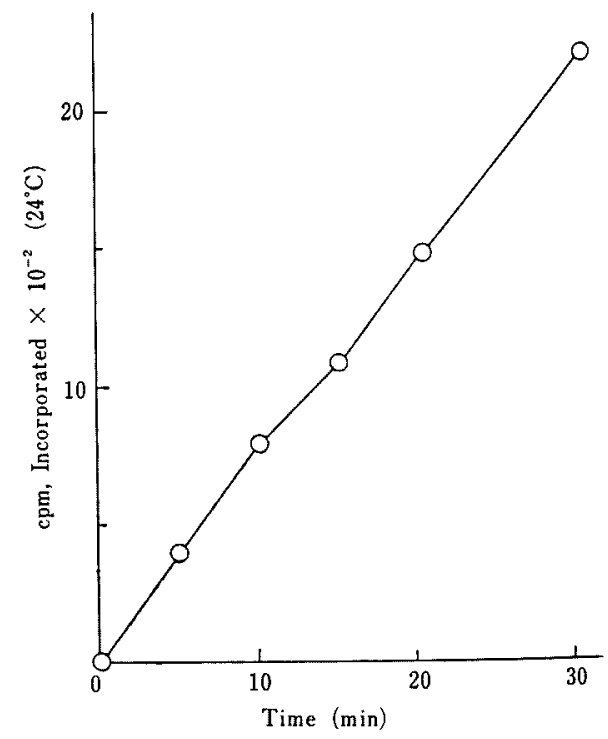

FIG. 11. Time Course of Chitin Synthesis Catalyzed by the Particulate Enzyme from $N$. crassa.

The reaction mixture contained $1.25 \mathrm{~mm}$ UDPGlcNAc- ${ }^{14} \mathrm{C} \quad(10,000 \mathrm{cpm}), 25 \mathrm{mM}$ Tris-HCl, 2.5 $\mathrm{mM} \mathrm{MgCl}, 0.25 \mathrm{mM}$ EDTA, $10 \mathrm{mM} \mathrm{GIcNAc}$ and $50 \mu \mathrm{l}$ of the enzyme solution from $N$. crassa in a total volume of $100 \mu \mathrm{l}, \mathrm{pH} 7.8$. Incubation was at $24^{\circ} \mathrm{C}$ for the periods indicated. 
formation of insoluble chitin was observed and the rate of the formation was linear over a period of $30 \mathrm{~min}$ (Fig. 11).

The effects of polyoxins $\mathrm{A} \sim \mathrm{M}$, deaminopolyoxin $A$ and uridine on the synthesis of chitin were investigated. The enzyme from $N$. crassa seemed to be somewhat sensitive for polyoxins compared with that from $P$. oryzae (Table VI). The data in Fig. 12 show-

TABLE VI. EFFECTS OF VARIOUS POLYOXINS ON ChItin Synthesis in $N$. crassa

The experiment was carried out as described in Fig. 11. Incubation was for $10 \mathrm{~min}$ at $24^{\circ} \mathrm{C}$.

\begin{tabular}{rrrr}
\hline $\begin{array}{l}\text { Amount of } \\
\text { polyoxins added, } \\
\mu \mathrm{g} / \mathrm{ml}\end{array}$ & $\begin{array}{c}\text { UDP-GlcNAc } \\
\text { incorporated } \\
\text { (m } \mu \text { mole/10 min) }\end{array}$ & $\begin{array}{l}\text { Percent } \\
\text { inhibition }\end{array}$ \\
\hline $\begin{array}{c}\text { None (control) } \\
\text { Polyoxin A }\end{array}$ & 5 & 12.8 & \\
B & 5 & 8.1 & 37 \\
C & 240 & 6.3 & 51 \\
D & 5 & 10.9 & 15 \\
E & 5 & 8.0 & 37 \\
F & 5 & 10.4 & 19 \\
G & 5 & 70.2 & 20 \\
H & 5 & 7.6 & 41 \\
J & 5 & 5.5 & 40 \\
K & 5 & 8.5 & 57 \\
L & 5 & 7.2 & 34 \\
M & 5 & 9.9 & 44 \\
Deaminopolyoxin A & & 23 \\
& 250 & 9.7 & 24 \\
\hline
\end{tabular}

ed that uridine was a competitor for UDPGlcNAc and the $K i$ value was $1.0 \times 10^{-3} \mathrm{M}$. This value was about one third of that obtained in the case of $P$. oryzae and differed scarcely from the $K m$ value for UDP-GlcNAc $\left(1.43 \times 10^{-3} \mathrm{M}\right)$, which has been reported by Endo et al. ${ }^{4 \prime}$

\section{DISCUSSION}

It has been considered that polyoxin $\mathrm{C}$ has no antifungal activity. ${ }^{8 !}$ Ohta et al. ${ }^{3)}$ reported that polyoxin $\mathrm{C}$ did not inhibit the incorporation of glucosamine $-{ }^{14} \mathrm{G}$ into cell wall

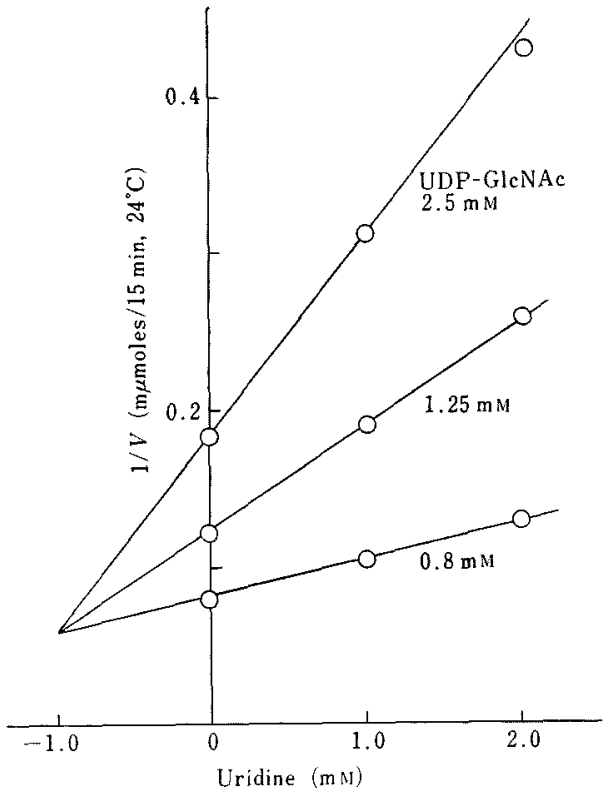

FIG. 12. Competitive Inhibition of Chitin Synthetase from $N$. crassa by Uridin.

The experiment was carried out as described in Fig. 11 except that the reaction mixture contained UDP-GlcNAc-14 C $(10,000 \mathrm{cpm})$ and uridine at the various concentrations indicated. Incubation was for $10 \mathrm{~min}$ at $24^{\circ} \mathrm{C}$. Data were plotted according to the Dixon plot.

chitin at the concentration of $50 \mu \mathrm{g} / \mathrm{ml}$. The findings described in this paper showed that polyoxin $\mathrm{C}$ and its derivatives inhibited the synthesis of chitin in cell free system in competition with UDP-GlcNAc. However, the $K i$ for polyoxin $\mathrm{C}$ is the same order as the $\mathrm{Km}$ for UDP-GlcNAc and is about $10^{3}$ times higher than those for other polyoxins. The reason why polyoxin $\mathrm{C}$ is inactive for growing or resting cells is that UDP-GIcNAc is presumably present at rather high concentration in intact fungal cells. At any rate, findings that $5^{\prime}$-amino- $5^{\prime}$-deoxyuridine which is a basal structure of polyoxins is a competitive inhibitor of the enzyme but carbamylpolyoxamic acid which corresponds to the part II of polyoxins has no activity, suggest the ab- 
solute need of the part I moiety for the inhibitory action of polyoxins.

It is suggested that the difference between activities of polyoxin $\mathrm{C}$ and other polyoxins is due to the affinity of the part II moiety for the enzyme. In polyoxin L, for instance, the $-\Delta g$ value for the part II is $3.5 \mathrm{kcal} / \mathrm{mole}$ and is about $40 \%$ of the $-\Delta G$ value for the whole molecule. And polyoxin $\mathrm{G}$ does not contain this moiety in its molecule. Amino group $(-\Delta g=2.1 \mathrm{kcal} / \mathrm{mole})$ at $\mathrm{C} 2{ }^{\prime \prime}$ position plays main role for the binding of Part II with the enzyme and hydroxyl group $(-\Delta g=$ $0.6 \mathrm{kcal} / \mathrm{mole}$ ) as a substituent for $\mathrm{R}_{3}$ is also important. Depending upon the varieties of substituents for $R_{1}$ and $R_{2}$, minor differences among the activities of polyoxins, except polyoxin $\mathrm{C}$, were observed. The component, which showed the highest activity, was polyoxin $\mathrm{J}$ containing a methyl group as $R_{1}$ and hydroxyl groups as $R_{2}$ and $R_{3}$. The sum of the $-\Delta g$ values for these three groups is 1.9 $\mathrm{kcal} / \mathrm{mole}$ and is about $20 \%$ of the $-\Delta G$ value for polyoxin $\mathrm{J}$.

As mentioned in "Results," $-\Delta G$ value for certain polyoxins and the sum of $-J g$ values for part I, part II and some groups constituting a polyoxin molecule were almost equal. In other words, the relation -$\lrcorner G \risingdotseq-\left(\Delta g_{1}+\right.$ $\left.\Delta g_{2}+\Delta g_{3}+\cdots \cdots\right)$ could be obtained. These results indicate that the so-called binding affinity concept is applicable to our investigation purposes.

In the inhibition process of chitin synthetase, inhibitor uridine and substrate UDP-GIcNAc are competitive and the $-\Delta G$ values for them are almost equal. From these facts, it is presumed that UDP-GlcNAc is bound tightly to the enzyme with its nucleoside moiety, ${ }^{*}$ while the residual part* of UDP-GlcNAc is bound loosely. It seems likely, therefore, that there are binding site and catalytic site on the chitin synthetase molecule and the uridine moiety of UDP-GIcNAc can attach to the binding

\footnotetext{
* See Scheme 2.
}

site. And presumably the inhibition of chitin synthetase by polyoxins is due to the competition between the part I of polyoxins and the nucleoside moiety of UDP-GlcNAc at the binding site on the enzyme molecule. In addition, the part II and the substituents for $R_{1}$ and $R_{2}$, may enhance markedly the binding of the part I to the enzyme. However, it is uncertain whether the part II and the $R_{2}$ substituent attach to the catalytic site. A structure of the binding site is presumably complementary to uridine and its derivatives with a substituent such as $-\mathrm{CH}_{3},-\mathrm{CH}_{2} \mathrm{OH}$ and $-\mathrm{COOH}$ at $\mathrm{C}^{\prime}$ position. The finding that the inhibitory activity of thymidine, a nucleoside containing methyl group at $\mathrm{C} 55^{\prime}$ position, was lower than that of uridine (Table III) was possibly due to lacking of the hydroxyl group at $\mathrm{C}_{2}{ }^{\prime}$ position of ribose moiety. In other word, it is assumed that the hydroxyl groups of ribose moiety of polyoxins contribute to the binding. Further studies will be necessary to elucidate the more defined role of the part II or the $\mathrm{R}_{2}$ substituents on the competitive inhibition of chitin synthetase.

The particulate enzyme from $P$. oryzae catalyzed the synthesis of insoluble chitin from UDP-GlcNAc in the presence of GlcNAc and soluble chitodextrin. Glaser et al. ${ }^{13)}$ reported that soluble chitodextrin was a primer of the reaction and soluble chitin synthetase had an absolute primer requirement. From our experiments, it is presumed that primer content in the particulate enzyme fraction depends upon preparation methods and varieties of fungi. When the primer content is not sufficient for chitin synthesis, the addition of soluble chitodextrin may be required.

Two particulate enzymes obtained from $P$. oryzae and $N$. crassa are different each other in some characteristics such as sensitivity for inhibitors, the $K m$ for UDP-GlcNAc and

13) L. Glaser and D. H. Brown, J. Biol. Chem., 228, 729 (1957). 
the requirement of activators. But it is not clear where these differences have derived from. In any case, the inhibition of chitin synthetase in $N$. crassa by polyoxins can be explained in the same manner as described in the case of $P$. oryzae.

The results of the experiments described in a series of our papers indicate that the primary action of polyoxins is the competitive inhibition of chitin synthetase. And in views of the chemical structure and the mechanism of action, polyoxin is a new type of the inhibitor of cell wall synthesis.

Acknowledgements. The authors wish to express their sincere thanks to Dr. Yusuke Sumiki, Emeritus Prefessor of Tokyo University for the guidance and encouragement to this work. Thanks are due to Dr. K. Isono, Dr. K. T. Hung, Dr. M. Murakami, Mr. I. Yamaguchi and Mr. H. Abe of The Institute of Physical and Chemical Research for their valuable advices to this work. We also wish to thank Miss K. Matsumoto for her excellent assistance. 